\title{
Motif Guru Memilih Metode Ceramah dalam Pembelajaran Sosiologi di SMAN 13 Padang
}

\author{
Janatul Aini ${ }^{1}$, Junaidi Junaid $i^{2}$ \\ ${ }_{1,2}$ Universtitas Negeri Padang \\ Email: janatulaini98@gmail.com, junaidiunp@fis.unp.ac.id
}

\begin{abstract}
Abstrak
Pembelajaran sosiologi mengharuskan guru menerapkan pembelajaran yang dapat mengaktifkan siswa, namun guru lebih sering memilih metode ceramah dalam pembelajaran sosiologi di SMA N 13 Padang. Tujuan dari penelitian ini adalah untuk mengetahui bagaimana motif guru dalam proses pembelajaran yang dilakukan di sekolah SMAN 13 Padang. Penelitian ini menggunakan metode kualitatif dengan tipe deskriptif. Teknik pengumpulan data dalam penelitian ini adalah wawancara, pengamatan dan studi dokumentasi. Hasil penelitian menunjukkan yang pertama, bahwa metode ceramah tidak perlu memerlukan banyak waktu Kedua, guru bisa berinteraksi dengan siswa. Ketiga, guru bisa melihat secara langsung sejauh mana siswa memahami materi yang disampaikan guru.
\end{abstract}

Kata kunci: Metode Ceramah, Motif Guru, Pembelajaran Sosiologi

\begin{abstract}
Sociology learning requires teachers to implement learning that can activate students, but teachers more often choose the lecture method in sociology learning at SMA N 13 Padang. The purpose of this study was to determine the motives of the teacher in the learning process carried out at SMAN 13 Padang. This research uses qualitative methods with descriptive type. Data collection techniques in this study were interviews, observation and documentation study. The results showed the first, that the lecture method did not need a lot of time. Second, the teacher could interact with students. Third, teachers can see directly the extent to which students understand the material presented by the teacher.
\end{abstract}

Key words: Motive, Lecture Method, Sociology Learning

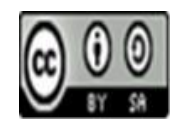

Received: December 15, 2020 Revised: February 10, 2021 Accepted: February 12, 2021

\section{Pendahuluan}

Pendidikan merupakan suatu proses perubahan sikap dan tingkah laku seseorang maupun sekelompok orang dalam usaha mendewasakan manusia melalui upaya pengajaran maupun Latihan (Poerwadarminta, 1985). Pendidikan adalah suatu bentuk investasi jangka panjang yang penting bagi seorang manusia (Suprihatin, 2015). Untuk mencapai proses perubahan sikap dan tingkah laku tersebut dapat ditempuh melalui proses pembelajaran formal di sekolah. Oleh karena itu kegiatan belajar mengajar sangatlah penting dan memiliki nilai yang tinggi dalam dunia pendidikan, terutama untuk meningkatkan kualitas proses dan hasil belajar yang lebih baik di sekolah. (Fitriyah, 2018)

Kurikulum merupakan salah satu hal yang harus dilaksanakan dalam proses belajar mengajar. Saat ini pembelajaran sosiologi di tingkat SMA mengacu pada kurikulum 2013. Tujuan kurikulum 2013 adalah mempersiapkan manusia Indonesia agar memiliki kemampuan hidup secara pribadi dan warga Negara yang beriman, produktif, kreatif, inovatif, dan afektif serta mampu berkonstribusi pada kehidupan bermasyarakat, berbangsa, bernegara, dan peradaban dunia (Sufairoh, 2016). Dalam proses pembelajaran di SMAN 13 Padang telah digunakan kurikulum 2013 sejak akhir tahun 2014. 
Ada beberapa model yang sering digunakan dalam pembelajaran sosiologi menurut kurikulum 2013, antara lain model pembelajaran discovery/inquiry, model pembelajaran berbasis masalah, model pembelajaran berbasis proyek, model pembelajaran kontekstual serta model pembelajaran kooperatif. Model pembelajaran discovery/inquiry merupakan suatu rangkaian kegiatan pembelajaran yang melibatkan secara maksimal seluruh kemampuan siswa untuk mencari dan menyelidiki secara sistematis, kritis, dan logis sehingga dapat menemukan sendiri pengetahuan, sikap, dan keterampilan sebagai wujud adanya perubahan tingkah laku. (Hanafiah, 2009). Model pembelajaran berbasis masalah merupakan model pembelajaran yang didasarkan pada banyaknya permasalahan yang membutuhkan penyelidikan autentik, yakni penyelidikan yang membutuhkan penyelesaian nyata dari permasalahan nyata. Model pembelajaran berbasis proyek merupakan model pembelajaran yang dilakukan untuk memperdalam pengetahuan dan keterampilan siswa dengan cara mebuat karya atau proyek yang terkait dengan materi ajar dan kompetensi. (Sani., 2013). Model pembelajaran kontekstual merupakan konsep belajar dengan cara mengaitkan antara materi yang diajarkan dengan dunia nyata dan mendorong siswa membuat hubungan antar pengetahuan yang dimiliki dengan penerapannya dalam kehidupan sebagai anggota masyarakat (Rusman, 2017) dan (Trianto, 2010). Sedangkan model pembelajaran kooperatif merupakan bentuk pembelajaran dengan siswa belajar dan bekerja dalam kelompokkelompok kecil secara kalaborasi yang anggotanya berdiri atas empat sampai enam orang yang bersifat heterogen (Risdiawati, 2012). Penggunaan model pembelajaran yang tepat bisa menjadi alternatif menghilangkan rasa jenuh siswa selama proses pembelajaran dan juga dapat meningkatkan antusiasme siswa dalam memperhatikan materi pembelajaran. (Fajri, Yoesoef, \& Nur, 2016). Semakin tepat metode yang digunakan oleh guru dalam mengajar, semakin efektif pula pencapaian tujuan pembelajaran.

Pemberlakukan kurikulum 2013 pada pembelajaran sosiologi di SMAN 13 Padang telah dimulai pada akhir tahun 2014 untuk kelas X hingga kemudian berlanjut ke kelas XI dan kelas XII. Dalam proses penerapannya, guru terlebih dahulu dibekali pengetahuan serta kemampuan agar dapat menerapkan pembelajaran sosiologi sesuai kurikulum 2013 dengan memberikan diklat kepada guru oleh instruktur kota, provinsi dan nasional baik diklat yang dilaksanakan di internal sekolah, LPMP Provinsi Sumatera Barat hingga pelatihan yang diikuti dilingkup nasional. Peneliti melakukan observasi pada proses pembelajaran sosiologi selama 6 bulan pada semester JuliDesember 2019 dan dan studi pendahuluan terhadap guru yang mengajar dan melakukan triangulasi sumber terhadap siswa untuk mengetahui pelaksanaan pembelajaran sosiologi di sekolah ini. Data yang peneliti peroleh dalam proses pelaksanaan pembelajaran guru masih dominan menggunakan metode ceramah dalam pembelajaran sosiologi, hal ini tentu saja bertolak belakang dengan rencana pembelajaran yang telah dirancang agar sesuai dengan kurikulum 2013 yang diberlakukan. Ada dua orang guru sosiologi yang mengajar di sekolah ini baik di kelas $\mathrm{X}$ hingga kelas XII. Berikut adalah data yang peneliti peroleh dari hasil studi pendahuluan terhadap pembelajaran sosiologi di SMAN 13 Padang.

Tabel 1. Tabel Metode Yang Digunakan Guru Sosiologi di SMAN 13 Padang

\begin{tabular}{rll|l}
\hline \multicolumn{1}{c}{ Tanggal Pengamatan } & Guru & \multicolumn{1}{c|}{ Metode yang digunakan } & \multicolumn{1}{c}{ Kelas } \\
\hline \multirow{2}{*}{ 22 Juli - 10 Agustus 2019 } & $\mathrm{R}$ & Metode Ceramah & X dan XII IPS \\
\cline { 2 - 4 } & $\mathrm{W}$ & Metode Ceramah & XI IPS \\
\hline \multirow{3}{*}{ 2 - 21 September 2019 } & $\mathrm{R}$ & Numbered Head Together & X dan XII IPS \\
\cline { 2 - 4 } & $\mathrm{R}$ & Metode Ceramah & X dan XII IPS \\
\cline { 2 - 4 } & $\mathrm{W}$ & Metode Ceramah & XI IPS \\
\hline
\end{tabular}

Sumber: Pengamatan Studi Pendahuluan Pada Semester Juli-Desember Tahun 2019 
Tabel di atas memperlihatkan pembelajaran sosiologi yang dilaksanakan guru sosiologi di SMAN 13 Padang dominan menggunakan metode ceramah, walaupun guru memahami metode ceramah merupakan aplikasi dari teacher centered leaning yang dapat digunakan dalam pembelajaran sosiologi sesuai kurikulum 2013 sebagai salah satu cara guru memberikan penguatan setelah siswa mengalami pengalaman belajar setelah mengimplementasikan langkah- langkah pembelajaran melalui model pembelajaran yang fokus pada student centered learning dan guru berfungsi sebagai fasilitator. Oleh karena itu peneliti melaksanakan penelitian terkait motif guru di SMAN 13 Padang tetap dominan menggunakan metode ceramah dalam proses membelajarkan pembelajaran sosiologi.

Berdasarkan pendapat dari (Risdiawati, 2012) motif adalah dorongan yang sudah terikat pada suatu tujuan. Motif menunjuk hubungan sistematis antara suatu respon dengan keadaan dorongan tertentu. Sedangkan pada pendapat (Sarwono, 2004) motif adalah suatu rangsangan yang menimbulkan ketegangan pada diri seseorang dan ketegangan itu mendorong orang yang bersangkutan untuk meredakannya.

Guru adalah orang yang memberikan ilmu pengetahuan kepada siswa, kemudian guru dalam pandangaan masyarakat adalah orang yang melaksanakan pendidikan di tempat-tempat tertentu tidak harus di lembaga pendidikan formal, tetapi bisa juga di masjid, di surau atau di mushola, di rumah dan sebagainya. Menurut Suprihartin (Suprihatin, 2015) guru merupakan seseorang yang memiliki ilmu yang memiliki tanggung jawab kepada siswa dan memiliki sikap profesional. Penjelasan di atas memberi pemaknaan bahwa guru adalah seorang tenaga didik yang mempunyai tanggung jawab yang tinggi dan memilki sikap profesional sehingga terciptanya suasana yang membuat siswa nyaman dalam proses pembelajaran.

Selanjutnya metode ceramah yang digunakan oleh guru menurut Syaiful Sagala (Sagala, 2011) merupakan suatu bentuk interaksi melalui penuturan lisan dari guru kepada siswa dalam proses pembelajaran. Dengan menggunakan alat-alat bantu seperti gambar, audio visual. Mahfuz Sholahuddin (Fitriyah, 2018) mengartikan bahwa metode ceramah adalah suatu cara penyampaian bahan pembelajaran secara lisan oleh guru di depan kelas.

Pembelajaran merupakan suatu sistem, yang terdiri dari berbagai komponen yang saling berhubungan satu dengan yang lain. Komponen tersebut, meliputi: tujuan, materi, metode, dan evaluasi (Rusman, 2017). Proses pembelajaran adalah upaya yang dilakukan untuk membuat siswa belajar, dalam belajar siswa tidak hanya berinteraksi dengan guru tetapi juga berinteraksi dengan keseluruhan sumber belajar yang digunakan untuk mencapai tujuan pembelajaran (Sunhaji, 2014). Pembelajaran sosiologi dimaksudkan mengembangkan kemampuan untuk memahami fenomena kehidupan sehari-hari. Materi pembelajaran mencakup konsep dasar dalam mengkaji berbagai fenomena dan permasalahan yang ada di masyarakat. (Pariera, 2015).

Tujuan belajar sosiologi adalah untuk merangsang keterlibatan siswa yang berkaitan dengan pengelolaan pengetahuan, nilai kemanusiaan dan keterlibatan sosial. Siswa dapat memiliki kemampuan memahami konsep-konsep sosiologi, memahami berbagai peran sosial dalam masyarakat, dan menumbuhkan sikap kepedulian sosial dalam hidup bermasyarakat (Sylvia, Anwar, \& Khairani, 2019). Selanjutnya artikel ini akan mendeskripsikan hasil penelitian motif guru menggunakan metode ceramah dalam proses pembelajaran sosiologi di SMAN 13 Padang.

\section{Metode Penelitian}

Pendekatan penelitian yang digunakan dalam penelitian ini adalah pendekatan kualitatif (Bungin, 2012). Penelitian kualitatif disebut dengan penelitian naturalistik karena penelitiannya dilakukan pada kondisi yang alamiah (Sugiyono, 2006). Pendekatan ini dipilih dengan maksud untuk mendapatkan pemahaman tentang motif guru menggunakan metode ceramah dalam pembelajaran sosiologi. Tipe penelitian yang digunakan dalam meneliti motif guru menggunakan metode ceramah dalam pembelajaran sosiologi di SMAN 13 Padang adalah studi 
kasus. Studi kasus adalah rancangan penelitian yang mengembangakan analisis mendalam atas suatu kasus (Idrus, 2009). Studi kasus menekankan pada satu atau beberapa kasus secara mendalam yang melibatkan beragam sumber informasi. Peneliti melaksanakan penelitian di kelas XII IPS, dengan alasan kelas tertinggi di tingkat SMA adalah kelas yang seharusnya dapat dipacu daya analisis siswanya, agar siswa dapat melakukan berbagai konstruksi terhadap fenomena yang diamati dan dapat menghubungkan antar konsep dari fenomena-fenomena sosial yang ada disekitarnya. Sehingga siswa kelas XII tidak lagi mendapatkan banyak informasi dari guru melalui pembelajaran sosiologi yang teacher centered (metode ceramah). sebagai motif guru menggunakan metode ceramah dalam pembelajaran sosiologi di SMAN 13 Padang.

Pemilihan informan dalam penelitian ini dilakukan melalui teknik purposive sampling. Teknik purposive sampling sampling adalah teknik penentuan sampel dengan pertimbangan tertentu, untuk menentukan siapa yang akan menjadi informan sesuai dengan data yang diinginkan (Sugiyono, 2006). Adapun jumlah informan yang dipilih sesuai kriteria yang telah peneliti tentukan sebanyak 20 orang yang terdiri dari 2 guru sosiologi, 15 siswa, 3 orang pimpinan sekolah.

Teknik pengumpulan data dalam penelitian ini adalah observasi dan wawancara. Observasi merupakan suatu proses yang komplek, suatu proses yang tersusun dari berbagai proses yang kompleks, dua diantaranya yang terpenting adalah proses-proses pengamatan dan ingatan (Sugiyono, 2006). Observasi adalah mengumpulkan data atau keterangan yang harus dijalankan dengan melakukan usaha pengamatan secara langsuang datang ketempat penelitian. Observasi umumnya digunakan sebagai metode untuk mengumpulkan data atau untuk mencatat bukti (Arikunto, 2008). Dalam penelitian ini, peneliti melakukan observasi proses pembelajaran sosiologi pada semester Juli-Desember 2019.

Kemudian teknik wawancara yang dilakukan dalam penelitian ini adalah wawancara mendalam. Wawancara mendalam merupakan suatu cara mengumpulkan data atau informasi dengan cara langsung bertatap muka dengan informan (Bungin, 2012). Melalui wawancara mendalam secara tatap muka, maka peneliti akan mendapatkan data mengenai permasalahan yang diteliti. Sebelum melakukan wawancara, peneliti menjalin hubungan baik bersama informan agar tercipta suasana nyaman dalam proses pengumpulan data. Terciptanya hubungan yang baik dan nyaman maka akan mempermudahkan peneliti mendapatkan informasi mendalam mengenai permasalahan yang diteliti. Selain itu, pertanyaan dirancang sesuai dengan pedoman wawancara, kemudian peneliti terus menggali jawaban dari informan dengan mengajukan beberapa pertanyaan agar lebih mendalam. Hasil wawancara tersebut peneliti catat dalam buku harian penelitian berdasarkan hasil rekaman wawancara. Rekaman hasil wawancara juga menjadi antisipasi oleh peneliti jika ada informasi yang luput selama proses observasi. Agar data yang diperoleh selama proses penelitian valid dan akurat maka dilakukan dengan teknik triangulasi data. Triangulasi data adalah teknik pengumpulan yang bersifat menggabungkan berbagai teknik pengumpulan data dan sumber data yang telah ada. Dengan melakukan triangulasi data, peneliti sekaligus sudah menguji kredibilitas data dan dengan melakukan triangulasi data akan lebih meningkatkan kekuatan data yang ditemukan peneliti. Peneliti melakukan triangulasi sumber kepada beberapa informan yang berbeda serta melakukan observasi pada kelas yang berbeda. Selain itu peneliti juga mendokumentasikan penelitian ini dalam bentuk foto dan rekaman video proses pembelajaran. Untuk menarik kesimpulan dari data yang diperoleh, maka diperlukan pengolahan data. Adapun langkah-langkah yang akan peneliti lakukan adalah; 1) Mengumpulkan data melalui wawancara, observasi dan sejumlah dokumen yang berkaitan, 2) Memeriksa data yang sudah terkumpul. 2) Menganalisis data yang sudah diperoleh. 3) Melakukan analisis deskriptif yang dipadukan dengan teori-teori. 4) Menyimpulkan, adapun hasil rekapitulasi panduan observasi dan panduan wawancara dalam penelitian ini dilampirkan.

Pada penelitian ini pengujian keabsahan data menggunakan teknik : (1) Perpanjangan Keikutsertaan, (Bungin, 2012) "Perpanjangan kekikutsertaan berarti peneliti tinggal di lapanganpenelitian sampai kejenuhan pengumpulan data tercapai", (2) Triangulasi, menurut Bungin (Bungin, 2012), "Triangulasi adalah teknik pemeriksaan keabsahan data yang 
memanfaatkan sesuatu yang lain di luar data itu untuk keperluan pengecekan atau sebagai pembanding terhadap data itu". Triangulasi dalam pengujian kredibilitas ini diartikan sebagai pengecekan data dari berbagai sumber dengan berbagai cara, dan berbagai waktu. Dengan demikian terdapat triangulasi sumber, triangulasi teknik pengumpulan data, dan waktu.

Triangulasi Teknik yang peneliti lakukan dalam penelitian ini yaitu dengan melakukan triangulasi teknik pengumpulan data seperti data yang diperoleh dengan wawancara kemudian dicek dengan observasi, dokumentasi. Bila dengan tiga teknik pengujian kredibilitas data tersebut menghasilkan data yang berbeda-beda, maka peneliti melakukan diskusi lebih lanjut kepada sumber data yang bersangkutan atau yang lain, untuk memastikan data mana yang dianggap benar. Atau mungkin semuanya benar, karena sudut pandangnya berbeda-beda. Hal ini sesuai dengan yang disampaikan oleh Sugiyono (2012: 373) menyatakan bahwa, triangulasi teknik untuk menguji kreadibilitas data dilakukan dengan mengecek data kepada sumber yang sama dengan teknik yang berbeda.

\section{Hasil dan Pembahasan}

Metode pembelajaran merupakan upaya untuk mengimplementasikan rencana yang sudah disusun dalam kegiatan nyata agar tujuan yang telah disusun tercapai secara optimal. Metode digunakan untuk merealisasikan strategi yang telah ditetapkan. Strategi menunjuk pada sebuah perencanaan untuk mencapai sesuatu, sedangkan metode adalah cara yang dapat digunakan untuk melaksanakan strategi. Dengan demikian suatu strategi dapat dilaksanakan dengan berbagai metode. Dengan demikian, metode dalam rangkaian sistem pembelajaran memegang peran yangsangat penting. Keberhasilan implementasi strategi pembelajaran sangat tergantung pada cara guru menggunakan metode pembelajaran, karena suatu strategi pembelajaran hanya mungkin dapat diimplementasikan melalui penggunaan metode pembelajaran. Oleh karena itu metode pembelajaran yang bisa digunakan untuk mengimpelementasikan strategi pembelajaran.

SMA Negeri 13 Padang adalah salah satu Sekolah Menengah Atas (SMA) berstatus negeri yang terletak di Kelurahan Balai Gadang, Kecamatan Koto Tangah, Kota Padang, Sumatera Barat. Struktur kepemimpinan SMA Negeri 13 Padang berjumlah 5 orang terdapat 62 orang guru bidang studi dengan berbagai mata pelajaran, serta berbagai sarana dan prasarana sekolah yang cukup baik sehinggga memudahkan siswa dalam proses pembelajaran.

Salah satu metode yang digunakan guru dalam proses pembelajaran sosiologi di SMAN 13 Padang adalah metode ceramah. Metode ceramah adalah penuturan bahan pelajaran secara lisan. Metode ini senantiasa bagus bila pengunaannya betul-betul disiapkan dengan baik, didukung alat dan media serta memperhatikan batas-batas kemungkinan penggunannya. Metode ceramah merupakan metode yang sampai saat ini sering digunakan oleh setiap guru. Hal ini selain disebabkan oleh beberapa pertimbangan tertentu, juga adanya faktor kebiasaan baik dari guru atau pun siswa. Guru biasanya belum merasa puas manakala dalam proses pengelolaan pembelajaran tidak melakukan ceramah. Demikian juga dengan siswa, mereka akan belajar manakala ada guru yang memberikan materi pelajaran melalui ceramah, sehingga ada guru yang berceramah berarti ada proses belajar dan tidak ada guru berarti tidak ada belajar. Metode ceramah merupakan cara yang digunakan untuk mengimplementasikan strategi pembelajaran ekspositori.

Metode ceramah adalah sebuah bentuk interaksi melalui penerangan dan penuturan lisan dari guru kepada siswa, dalam pelaksanaan metode ceramah untuk menjelaskan uraiannya, guru dapat menggunakan alat-alat bantu seperti gambar, dan audio visual lainnya. Tujuan metode ceramah adalah menciptakan landasan pemikiran siswa melalui produk ceramah yaitu bahan tulisan siswa sehingga siswa dapat belajar melalui bahan tertulis hasil ceramah. Kelebihan dari metode ceramah salah satunya adalah siswa langsung menerima ilmu pengetahuan yang disamapaikan guru. Dengan demikian Kurikulum 2013 menekankan pada keaktifan siswa atau siswa. Guru berperan sebagai fasilitator bagi siswa dalam belajar. Dalam pelaksanakan kurikulum 2013, guru sudah dibekali pengetahuan serta kemampuan mengenai kurikulum 2013 dengan 
adanya sosioalisasi terhadap guru-guru sudah dibekali pengetahuan serta kemampuan mengenai kurikulum 2013 dengan adanya sosialisasi terhadap guru-guru sudah dibekali pengetahuan serta kemampuan mengenai kurikulum 2013 dengan adanya sosialisasi terhadap guru.

Di SMAN 13 Padang terdapat dua orang guru Sosiologi, yaitu Ibu R dan Bapak W. Peneliti mengamati Ibu $\mathrm{R}$ dalam mengajar. Ibu $\mathrm{R}$ lebih sering menggunakan ceramah dalam melaksanakan pembelajaran sebab metode ceramah membuat minat belajar siswa meningkat karena metode ceramah sangat mudah dipahami dan ditambah apabila guru mengaitkan materi pembelajaran dengan contoh dalam kehidupan sehari-hari. Bapak berinisial W selalu menggunakan metode ceramah dnegan mengaitkan contoh dalam kehidupan sehari-hari tentang materi pembelajaran yang dibahas.

Tabel di bawah ini dijelaskan daftar nama guru Sosiologi di SMA Negeri 13 Padang. Pada tabel di bawah ini terdapat 2 orang guru sosiologi yang mengajar di SMAN 13 Padang dijelaskan tamatan/jurusan, status kepegawaian, mulai mengajar serta jumlah jam mengajar.

\section{Tabel 2. Tabel Daftar Guru Sosiologi di SMAN 13 Padang}

\begin{tabular}{ccccc} 
Nama & $\begin{array}{c}\text { Tamatan/ } \\
\text { Jurusan }\end{array}$ & $\begin{array}{c}\text { Status } \\
\text { Kepegawaian }\end{array}$ & $\begin{array}{c}\text { Mulai } \\
\text { Mengajar }\end{array}$ & $\begin{array}{c}\text { Jumlah Jam } \\
\text { Mengajar }\end{array}$ \\
\hline RV & Filsafat Sosiologi & PNS & 2006 & $\begin{array}{c}29 \text { jam setiap } \\
\text { minggu }\end{array}$ \\
\hline IA & $\begin{array}{c}\text { Pendidikan } \\
\text { Sosiologi }\end{array}$ & Honor & 2016 & 20 jam perminggu \\
\hline
\end{tabular}

Sumber: Data SMAN 13 Padang

Tabel di atas memperlihatkan bahwa di SMA Negeri 13 Padang terdapat 2 orang guru bidang studi sosiologi dengan status 1 orang PNS dan 1 orang Honorer, jumlah jam mengajar pun berbeda guru yang pertama 29 jam setiap minggu sedangkan guru yang ke 2 hanya 20 jam perminggu. Hasil penelitian yang peneliti lakukan mengungkapkan berbagai motif guru masih menggunakan metode ceramah dalam proses pembelajaran sosiologi di SMAN 13 Padang.

Peneliti melakukan observasi pada pembelajaran sosiologi pada semester Juli-Desember 2019 untuk mengetahui motif guru menggunakan metode ceramah dalam pembelajaran. Selain itu juga peneliti melakukan wawancara kepada guru, siswa dan pimpinan sekolah. Berikut hasil penelitian mengenai motif guru menggunakan ceramah dalam pembelajaran sosiologi di SMAN 13 Padang.

\section{Menghemat Waktu}

Motif guru dalam memilih metode ceramah dalam proses pembelajaran sosiologi di SMAN 13 Padang. Pertama penerapan metode ceramah tidak perlu memerlukan banyak waktu sehingga proses pembelajaran tidak merasakan bosan dan pembelajaran terasa sangat menyenangkan. Dalam penerapan metode ceramah yang diterapkan oleh guru sangat dipahami oleh siswa dan penerapan yang dilakukan oleh guru membuat siswa mengerti dengan materi yang disampaikannya serta proses pembelajaran juga terasa sangat menyenangkan. Sehingga waktu yang dibutuhkan oleh guru untuk menyampaikan materi tidak terlalu lama selebihnya ditugaskan oleh guru untuk membuat soal-soal latihan atau kuis agar siswa mengerti dengan materi yang disampaikan guru.

Dari hasil penelitian setelah peneliti mewawancarai ibuk RV, menjelaskan bahwa penerapan metode ceramah sangat mudah dipahami oleh siswa dan penggunaaan metode ceramah ini dapat menghemat waktu sehingga tidak perlu untuk memerlukan alat khusus untuk menjelaskan pembelajaran cukup dengan guru memberikan contoh dikehidupan nyata yang berkaitan dengan isi materi yang diajarkan, berikut penuturan beliau. 
"Penerapan metode ceramah ini sangat mudah dipahami oleh siswa dan dalam proses pembelajaran tidak perlu memerlukan banyak waktu, dalam penerapan metode ceramah guru menjelaskan terlebih dahulu $\mathrm{KD}$ atau inti materi yang akan disampaikan kepada siswa, cara penyampaian dalam pembelajaran harus memilliki cara bicara yang mudah agar bisa dimengerti oleh siswa, dan dalam metode ceramah tidak perlu memerlukan alat khusus dalam menjelaskan suatu pembelajaran cukup dengan guru memberikan contoh di kehidupan nyata kepada siswa sehingga mudah dimengerti dan dipahami oleh siswa".

(Disampaikan dalam Bahasa Indonesia).

Hal yang sama juga disampaikan oleh siswa bernama NR kelas XII IPS 3.

"Baraja jo metode ceramah ko di ibuk sero buk,capek mangarati wak jo materi yang di sampaian guru tu buk, siap tu waktu wak pas baraja tu ndak taraso di ibuk do wak indak lo terlalu kaku bana di ibuk do apolagi pembelajaran sosiologi di ibuk tu sero ma, guru tu maagiah contoh di ibuk yang dakek-dakek jo awak di ibuk, mode kehidupan nyato wak raso di ibuk, materi yang disampaian tu terperinci di buk contoh yang diagiah tu di ibuk babeda-beda tu ndak bosan wak dibueknyo do buk." (Disampaikan dalam Bahasa Minangkabau)

Artinya:

"Belajar dengan menggunakan metode ceramah ini menyenangkan buk, cepat mengerti dengan materi yang disampaikan guru buk, setelah itu waktu belajar yang digunakan tidak terasa buk, pembelajaran yang dilakukan tidak terlalu kaku, apalagi pembelajaran sosiologi buk sangat menyenangkan sekali, guru memberikan contoh kepada siswa sangat berkaitan dengan kehidupan nyata jadi rasa jadi kenyataan pada diri peeserta didik, materi yang disampaikan itu terperinci buk, contoh yang diberikan berbeda-beda sehingga dalam proses pembelajaran tidak merasakan bosan".

Hal yang sama juga disampaikan oleh siswa bernama RPD Dewi kelas XII IPS2. "Baraja jo metode ceramah ko sabanta mamakan waktu nyo buk jadi sero wak baraja tugas mancatat indak ado di ibuk do jadi waktu baraja tu indak taraso do pas di akhir beko ado guru tu batanyo tu di jawek di ibuk tu sero jadi, ndak bosan wak di buek di ibuk do".

(Disampaikan dalam Bahasa Minangkabau).

Artinya:

"Belajar dengan menggunakan metode ceramah ini sebentar menggunakan waktu buk, jadi menyenangkan, tugas mencatat tidak ada, waktu belajar tidak terasa, pada akhir pembelajaran guru bertanya kepada siswa kemudian dijawab oleh siswa pembelajaran seperti itu membuat siswa merasa senang".

Hal yang sama juga disampaikan oleh peserta didik bernama SM kelas XII IPS 2.

"Baraja jo metode ceramah ko ngarati wak buk dari pado jo bahaso buku, kadang guru ko ado yang manjalehan pakai bahaso buku tu indak mangarati awak di ibuk do katokatonyo tu berbelit-belit buk jadi wak kurang paham buk,apolagi baraja sosiologi di ibuk tu sero buk wak paliang suko materi interaksi tu buk, paham wak jo materi yang di sampaian guru tu buk". (Disampaikan dalam BahasaMinangkabau).

Artinya:

"Belajar dengan menggunakan metode ceramah ini mengerti buk, dari pada menggunakan bahasa buku, terkadang ada guru yang menjelaskan materi dengan 
menggunakan bahasa buku, kata-kata yang dijelaskan berbelit-belit buk jadi saya kurang paham,apalagi belajar sosiologi buk, menyenangkan, saya suka sama materi interaksi sosial buk, paham saya dengan materi yang disampaikan".

Dari penjelasan di atas menguatkan asumsi bahwa motif guru dalam menerapkan metode ceramah dalam proses pembelajaran tidak perlu memerlukan banyak waktu karena jika waktu yang digunakan guru hanya untuk ceramah di depan kelas membuat siswa jenuh dan bosan sehingga proses pembelajaran yang dilakukan guru tidak menyenangkan, sehingga waktu yang dibutuhkan oleh guru untuk menyampaikan materi tidak terlalu lama selebihnya ditugaskan oleh guru untuk membuat soal-soal latihan atau kuis agar siswa mengerti dengan materi yang disampaikan guru.

Metode ceramah yang dilaksanakan guru dalam proses pembelajaran sangatlah menarik salah satunya adalah guru bisa berinteraksi dengan siswa sehingga ada interaksi langsung yang diberikan guru kepada siswa agar proses pembelajaran yang dilakukan berjalan secara maksimal, materi seperti apa yang tidak mereka pahami mereka bisa bertanya kepada guru ada interaksi anatara siswa dengan guru dan ada respon timbal balik juga antara mereka sehingga proses pembelajaran yang mereka jalani tidak terasa dan tidak membosankan. Selain menghemat waktu dan guru bisa berinteraksi langsung dengan siswa .

Penjelasan di atas mengungkapkan realita bahwa metode ceramah merupakan metode yang 'murah' dan 'mudah' untuk dilakukan. Murah dalam arti proses ceramah tidak memerlukan peralatan-peralatan yang lengkap, berbeda dengan metode yang lain seperti demonstrasi atau peragaan. Sedangkan mudah, memang ceramah hanya mengandalkan suara guru, dengan demikian tidak terlalu memerlukan persiapan yang rumit. Selain itu metode ceramah juga dapat menyajikan materi pelajaran yang luas. Artinya, materi pelajaran yang banyak dapat dirangkum atau dijelaskan pokok-pokoknya oleh guru dalam waktu yang singkat.

Sesuai dengan Teori yang digunakan dalam penelitian ini adalah teori tindakan sosial yang dikemukakan oleh Max Weber (Ambo, 2010) terlihat bahwa motif guru memilih metode ceramah dalam pembelajaran sosiologi merupakan tindakan sosial dimana asumsi dasar dari tindakan sosial adalah tindakan individu sepanjang tindakannya itu mempunyai makna atau arti subjektif bagi dirinya dan diarahkan pada tindakan orang lain, dimana peneliti melihat adanya suatu tindakan atau tanggapan ketika guru menerangkan suatu pembelajaran siswa akan cepat tanggap atau memberikan respon tentang pembelajran yang dijelaskan oleh guru tersebut, sehingga suatu pembelajaran bisa berjalan dengan baik.

\section{Terjadinya Interaksi yang Edukatif antara Guru dan Siswa}

Metode ceramah yang dilaksanakan oleh guru dalam proses pembelajaran sangatlah menarik salah satunya adalah guru bisa berinteraksi dengan siswa sehingga ada interaksi langsung yang diberikan guru kepada siswa agar proses pembelajaran yang dilakukan berjalan secara maksimal. Materi yang tidak mereka pahami bisa ditanyakan langsung kepada guru sehingga antara guru dan siswa terjadi respon timbal balik dan pembelajaran menjadi tidak membosankan. Guru juga dapat menanamkan nilai-nilai spiritual dan sosial kepada siswa melalui contoh-contoh yang disampaikan selama proses pembelajaran.

Berikut pemaparan data wawancara yang mendukung pernyataan di atas. Penuturan guru sosiologi SMA Negeri 13 Padang Bapak IA sebagai berikut.

"Metode ceramah sangat mudah dilakukan kepada siswa karena dalam penerapan metode ceramah keadaan siswa berinteraksi langsung dengan guru sehingga ada respon timbal balik antara guru dengan siswa materi seperti apa yang tidak dimengerti siswa mereka bisa tanyakan kepada guru sehingga tidak perlu memerlukan peralatan khusus untuk menyampaikan sebuah materi dalam pembelajaran cukup hanya dengan membawa mereka ke dalam contoh dunia nyata ynag mereka alami.dalam penerapan metode ceramah guru lebih atif dari siswa sehingga guru harus memahami materi yang 
akan disampaikan kepada siswa sehingga proses pembelajaran dapat berjalan dengan baik" (disampaikan dalam Bahasa Indonesia).

Hal yang sama juga disampaikan oleh siswa bernama Jeni Novrianti kelas XII IPS 1. "Metode ceramah yang disampaian guru di sekolah SMA Negeri 13 Padang ko lai sero buk, ado interaksi langsuang antaro guru jo siswa sahinggo mangarati kami jo materi yang disampaikannyo buk, materi apo yang disampaian ibuk tu lai lancar buk soalnyo mudah kami memahaminyo buk, apolagi materi yang dijalehan tu jaleh di ibuk tu murah kami memahaminyo di ibuk nyo. Misalnyo kalau wak kurang jaleh samo materi yang disampaikan ibuk tu bisa wak batanyo buk,soalnyo ado umpan baliak guru jo siswa buk,mangkonyo murah kami manggarati buk.

(Disampaikan dalam Bahasa Minangkabau)

Artinya :

"Metode ceramah yang disampaikan guru di sekolah SMA Negeri 13 Padang ini menyenangkan buk, ada interaksi langsung anatara guru dengan siswa sehingga mengerti dengan materi yang disampakaikan buk, materi apapun yang disampaikan buk guru berjalan dengan lancar dan baik buk, soalnya mudah kami memahaminya buk, apalagi materi yang disampaikan oleh buk guru jelas dan mudah untuk dipahami. Misalnya kalau kita kurang mengerti yang beliau sampaikan kita bisa bertanya langsung soalnya ada interaksi yang terjadi sehingga mudah untuk memahami”.

Hal yang sama juga disampaikan oleh siswa bernama Rahmad Saputra kelas XII IPS 2.

"Metode ceramah ko sero buk lai masuak akal a materi yang disampaian tu kadalam utak wak buk tapi kalau metode diskusi yang di suruah ibuk tu kebanyakan kami maota buk yang mambuek tugas diskusi tu surang tu a buk yang lain sibuk jo urusan nyo surang kadang ado karajo kalua masuak kalua masuak a,ndak ado kompak dalam kelompok di ibuk do jadi kawan surang ko lah yang bakarajo di ibuk" (wawancara Tanggal 24 Agustus 2020, dalam Bahasa Minangkabau)

\begin{abstract}
Artinya:
"Metode ceramah sangat menyenangkan dan masuk akal apapun materi yang disampaikan kedalam otak kami buk, tapi kalau metode diskusi yang di tugaskan oleh guru kebanyakan kami ngobrol dan ngegibah buk,yang membuat tugas diskusi hanya satu orang teman yang mengerjakannya buk, yang lain sibuk keluar masuk kelas, tidak ada kekompakan dalam kelompok buk,jadi hanya satu orang teman saja yang mengerjakan tugas kelompok".
\end{abstract}

Dari penjelasan di atas mengatakan bahwa motif guru dalam menerapkan metode ceramah dalam proses pembelajaran adalah guru bisa berinteraksi langsung dengan siswa sehingga proses pembelajaran terasa sangat menyenangkan, materi seperti apa yang tidak mereka pahami mereka bisa bertanya kepada guru ada interaksi anatara siswa dengan guru dan ada respon timbal balik juga antara mereka sehingga proses pembelajaran yang mereka jalani tidak terasa dan tidak membosankan.

Sesuai dengan teori oleh Max Weber (Ambo, 2010), jadi metode ceramah termasuk tindakan sosial instrumental rasional. Tindakan ini merupakan suatu tindakan sosial yang dilakukan seseorang didasarkan atas pertimbangan dan perhitungan yang sadar yang berhubungan dengan tujuan tindakan itu dan ketersediaan alat yang digunakan untuk mencapainya, dimana seorang guru harus bisa menciptakan ide yang kreatif sehingga dalam proses pembelajrannya bisa membuat siswa lebih tertarik untuk menggali lebih dalam lagi tebtang suatu pembelajran sehingga terciptanya suatu pembeljaran yang menarik. 


\section{Memahami Penguasaan Materi Siswa}

Motif guru melaksanakan pembelajaran sosiologi menggunakan metode ceramah adalah guru dapat melihat secara langsung sejauh mana siswa memahami materi yang disampaikan guru. Berdasarkan data observasi peneliti lakukan pada bulan Juli-Desember 2019 di SMA Negeri 13 Padang dari hasil pengamatan yang peneliti lakukan bahwa metode ceramah yang dilaksanakan oleh guru pada proses pembelajaran adalah guru bisa melihat secara langsung sejauh mana siswa memahami materi yang disampaikan guru, mengerti atau tidak materi yang disampaikan, dari respon siswa guru bisa melihat kemampuan yang mereka miliki sehingga nilai yang diperoleh atas dasar kemampuan yang mereka miliki.

Untuk mendapatkan data peneliti juga mewawancarai salah seorang siswa bernama VK kelas XII IPS 4.

"Metode ceramah ko sero buk capek manggarati wak baraja dinyo buk,materi yang disampaian guru tu sero lo di ibuk, ditunjuan jo contoh-contoh di ibuk tu capek manggarati wak dinyo, kadang ado guru tu bisa malawak jadi wak ndak terlalu fokus baraja di ibuk do ado galak-galak gai dan carito-carito disitu capek mangarati wak jo materi yang disampaian tu buk" (Disampaikan dalam Bahasa Minangkabau).

Artinya:

"Metode ceramah ini menyenangkan buk, cepat mengerti dalam proses pembelajaran buk dan materi yang disampaikan guru menyenangkan buk, terkadang diberitahu dengan contoh-contoh agar kami cepat mengerti, kadang ada guru yang bisa membuat hiburan agar dalam proses pembelajaran tidak terlalu fokus dalam pembelajaran tersebut sehingga kami cepat mengerti dengan materi yang disampaikan buk".

Hal yang sama juga disampaikan oleh siswa bernama Ayu Anjanai kelas XII IPS2. "baraja jo metode ceramah ko sero buk soalnyo guru bisa tau siapo yang paham jo materi yang disampaikan guru, jadi guru tu bisa maliek sacaro langsuang jo nyato ma siswa yang aktif dan ma yang indak buk,sia yang curhat-curhat dan main-main dalam baraja ibuk tu tau manilai buk" (Disampaikan dalam Bahasa Minangkabau)

Artinya:

"Belajar dengan mengunakan metode ceramah ini sangat menyenangkan buk karena guru bisa tau siapa yang paham dan mengerti dengan materi yang disampaikan guru,jadi guru bisa melihat secara langsung dan nyata mana siswa yang tidak aktif buk, siapa yang ngobrol dan main-main dalam pembelajaran guru tau menilainya buk".

Dari penjelasan di atas dapat diketahui bahwa motif guru dalam menerapkan metode ceramah dalam proses pembelajaran adalah guru bisa mengetahui langsung pemahaman siswa terhadap materi yang disampikan guru, sehingga jika ada dari siswa tidak paham maka bisa langsung bertanya kepada guru bagian mana yang tidak dipahami sehingga guru dapat mengulangi atau memberikan penjelasan secara singkat tentang bagian yang kurang dipahaminya, sehingga akhirnya peserta didik dapat paham dalam pembelajaran sosiologi.

Dalam penjelasan mengenai teori tindakan sosial yang dikemukakan oleh Max Weber (Hidayat, 2011) bahwa suatu tindakan instrumental rasional didasarkan atas pertimbangan guru memilih metode ceramah dalam proses pembelajaran apakah siswa bisa memahami materi yang disampaikan guru sehingga proses pembelajaran terasa sangat menyenangkan ada interaksi langsung antara siswa dengan guru, guru ditugaskan sebagai aktor dalam proses pembelajaran sangat berperan aktif mengambil keputusan seperti guru berhak bertanya kepada siswa atau memberikan kuis agar siswa mengerti dengan materi yang disampaikan guru. 
Interaksi yang tercipta dalam pembelajaran merupakan perilaku yang biasa dikategorikan sebagai tindakan sosial. Dimana tindakan sosial merupakan proses aktor terlibat dalam pengambilan-pengambilan keputusan subjektif tentang sarana dan cara untuk mencapai tujuan tertentu yang telah dipilih, tindakan tersebut mengenai semua jenis perilaku manusia, yang ditunjukan kepada perilaku orang lain, yang telah lewat, yang sekarang dan yang diharapkan diwaktu yang akan datang. Weber secara khusus mengklasifikasikan tindakan sosial yang memiliki arti-arti subjektif tersebut kedalam empat tipe. Atas dasar rasionalitas tindakan sosial, Weber membedakan tindakan sosial manusia kedalam empat tipe, semakin rasionalitas tindakan sosial itu semakin mudah dipahami. (Damsar, 2011).

\section{Kesimpulan}

Berdasarkan hasil penelitian yang dilakukan di SMAN 13 Padang, guru sosiologi menggunakan metode ceramah dalam proses pembelajaran mempunyai alasan tersendiri antara lain pertama metode ceramah sangatlah menghemat waktu, sehingga siswa tidak cepat merasa bosan dalam belajar. Kedua guru bisa berinteraksi dengan siswa sehingga ada interaksi langsung yang diberikan guru kepada siswa agar proses pembelajaran yang dilakukan berjalan secara maksimal, ketiga guru bisa melihat secara langsung penguasaan materi siswa, jika ada beberapa dari siswa yang tidak mengerti bisa langsung bertanya kepada guru bagian mana yang siswa tidak mengerti.

\section{Daftar Pustaka}

Ambo, U. (2010). Tradisi Aliran dalam Sosiologi dari Filosofi Positivistik ke Post Positivistik (2010th ed.). Jakarta: Rajawali Perss.

Arikunto, S. (2008). Penelitian Tindakan Kelas. Jakarta: Bumi Aksara.

Bungin, B. (2012). Metodologi Penelitian Kualitatif, Aktualiasasi Metodologis ke Arah Ragam Varian Kontemporer. Jakarta: PT Raja Grafindo Persada.

Damsar, D. (2011). Pengantar Sosiologi Pendidikan. Jakarta: Kencana Prenada Media Group.

Fajri, N., Yoesoef, A., \& Nur, M. (2016). Pengaruh Model Pembelajaran Koperatif Tipe Talking Stick Dengan Stretegi Joyful Learning Terhadap Prestasi Belajar Siswa Pada Mata Pelajaran Ips Kelas VII MTsN Meuraya Banda Aceh. Jurnal Ilmiah Mahasiswa Pendidikan Sejarah, 1(1), 98-109.

Fitriyah, A. Y. dan N. (2018). Efektivitas Penyuluhan Metode Ceramah dan Audiovisual dalam Meningkatkan Pengetahuan Dan Sikap Tentang Sadari di SMKN 5 Surabaya. Promkes.

Hanafiah, H. (2009). Konsep Strategi Pembelajaran. Bandung: Refika Aditama.

Hidayat, R. (2011). Perspektif Sosiologi tentang Kurikulum. Jurnal Pendidikan Dan Kebudayaan, 17(2), 178. https://doi.org/10.24832/jpnk.v17i2.16

Idrus, M. (2009). Metode Penelitian Ilmu Sosial. Bandung: Pustaka Setia.

Pariera, S. (2015). Pentingnya Rancangan Pembelajaran Sosiologi Bagi Dunia Pendidikan di Timor Leste. Jurnal Inovasi Dan Teknologi Pembelajaran, 1(2), 109.

Poerwadarminta, W. J. S. (1985). Kamus Umum Bahasa Indonesia. Jakarta: Balai Bahasa. Ramadhani, A. (2019). Hubungan Motif Bermain Game Online dengan Perilaku Agresivitas Remaja Awal (Studi Kasus di Warnet Zerowings, Kandela dan Mutant di Samarinda). EJounal Ilmu Komunikasi, 1(1), 136-158.

Rusman, R. (2017). Belajar Dan Pembelajaran Berorientasi Standar Proses Pendidikan. Jakarta: Kencana.

Sagala, S. (2011). Konsep dan Makna Pembelajaran. Jakarta: Alfabeta Sani., A. (2013). Inovasi Pembelajaran. Jakarta: Bumi Aksara. 
Sufairoh, S. (2016). Pendekatan Saintifik Dan Model Pembelajaran K-13. Jurnal Pendidikan Profesional, 5(3), 116-125.

Sugiyono, S. (2006). Metode Penelitian Kualitatif, Kualitatif dan R\&D. Bandung: Alfabeta.

Sunhaji, S. (2014). Konsep Manajemen Kelas Dan Implikasinya Dalam Pembelajaran. Jurnal Kependidikan, 2(2), 30-46.

Suprihatin, S. (2015). Upaya Guru Dalam Meningkatkan Motivasi Belajar Siswa. Jurnal Pendidikan Ekonomi, 3(1), 73-82.

Sylvia, I., Anwar, S., \& Khairani, K. (2019). Pengembangan Instrumen Penilaian Autentik Berbasis Pendekatan Authentic Inquiry Learning Pada Mata Pelajaran Sosiologi di Sekolah Menengah Atas. Socius, 6(2), 103-120. https://doi.org/10.24036/scs.v6i2.162

Trianto, T. (2010). Model Pembelajaran Terpadu. Jakarta: Bumi Aksara. 